\title{
Experimental Investigation on the Effects of Airborne Dusts on the Power Output and Efficiency of Photovoltaic Cells
}

\author{
Raviduth RAMFUL \\ Mechanical and Production Engineering Department \\ University of Mauritius, Réduit, Mauritius
}

\begin{abstract}
The energy output of a solar-energy harvesting system is mainly related with the sun's irradiance and also other factors such as the environment, climatic conditions and components' performance. This research study focuses on an experimental investigation involving a clean and an artificially polluted photovoltaic panels in an attempt to evaluate the effects of airborne dusts, namely, soil, sand and rock sand on the efficiency and power output of photovoltaic system. The selection of air pollutants were based on the emergence of solar farms in tropical climates according to IS/IEC 61724:1998 [1]. The particles' composition and size were varied and the panels were setup identically under same environmental conditions. After analyzing and comparing the recorded data, the efficiency and energy yield reduction values were found to be affected by three main factors, namely, the type, amount and particle-size of the composition. The pollutant particles to have the most significant impact on the power generation were found to be soil particles of 63 microns followed by rock sand particles of 75 and $63 \mu \mathrm{m}$.
\end{abstract}

Key words: airborne dust, photovoltaic, experimental analysis, energy yield reduction

\section{INTRODUCTION}

The most abundant energy resource on the globe is solar energy. The amount of energy consumed by all the human activities in a year is the same as the solar energy that strikes the earth's surface in the lapse time of one hour. Photovoltaics is among the three main solar active technologies which convert direct sunlight into electricity. The remaining two are the solar thermal collectors for heating and cooling (SHC) and the concentrating solar power (CSP). In today's era, PV represents only $0.1 \%$ of the total global electricity generation [2]. The rapid expansion of PV technology in Mauritius resulted from favorable policies taken in the sustainable development sector as well as a reduction in the manufacturing cost of PV panels worldwide. In nearly all over the world, PV is a commercially accessible and reliable technology with significant potential for long term growth. According to the solar PV roadmap vision of the International Energy Agency (IEA), PV is estimated to produce 5\% of the global electricity in 2030 , rising to $11 \%$ in 2050 [2].

According to the Mauritius Meteorological Services, MMS, Mauritius, situated at about $890 \mathrm{~km}$ to the east of Madagascar, benefits from a favorable solar climate with approximately about 2000 to 2250 hours of sunshine annually and a mean solar radiation of $5.4 \mathrm{kWh}$ per $\mathrm{m}^{2}$ per day [3]. Photovoltaic technology is already in use in Mauritius, namely at the MCB building in Ebène, where 2000 photovoltaic modules have been installed for a net production amounting to $430 \mathrm{~kW}$ [4]. Sarako PVP Co. Ltd which implemented a photovoltaic farm at Bambous, comprises of about 62,000 modules and has a total production capacity of 15MW. In 2008, the Government of Mauritius adopted a new strategy, Mauritius Ile Durable (MID), i.e. to become a sustainable developing nation and to uplift the standard of living of its people [5]. One of the many projects of MID to be implemented by the Energy Service Division (ESD), was the installation of 5kW PV systems in ten Government schools across the island [3].

Currently, photovoltaic system is winning all over the world interest and is intended to play a key role in sustainable energy development. PV system installed capacity has more than doubled since 2007 reaching to almost $21 \mathrm{GW}$ in 2009 as shown in fig. 1 [6]. In china for instance, the reported demand for new solar installations is

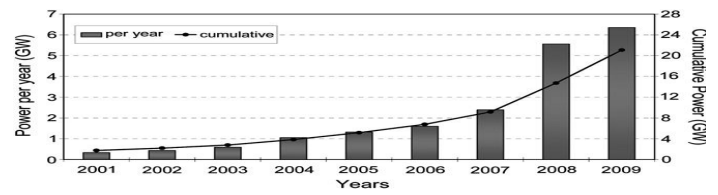
high as $232 \mathrm{MWp}$ each year. Its government has announced to expand the installed capacity to up to $1800 \mathrm{MWp}$ by the year 2020 [7].

Worldwide PV system operations are mostly met in central grid power stations and grid-connected rooftop or façade installations, that is building integrated photovoltaic. The continuous development and rapid Figure 1. Cumulative and annual PV installations globally [6] 
evolution in photovoltaic technology will only benefit to the customers due to their better affordability.

A considerable impact of the air pollution on PV panels and solar collector's normal functioning has been reported in recent years [6]. As published by Fenger [8] and Ramanathan and Feng [9], air quality is considerably aggravated by suspended contaminant particles that come from both the human daily action and natural processes. Denholm et al. [10] observed that the reduction in efficiency of PV modules ranged from 10 to $13 \%$ at commercial level while for outdoor installed modules, that may be further decreased by 10 to $25 \%$ due to the losses in the inverter, wiring and dust pollution. Dust deposition may negatively influence the energy performance of solar technologies, namely in PVs and solar collectors [11].

The objective of this research was to setup an experiment where the impact of dust particles on the efficiency of PV panels would be evaluated. Photovoltaic (PV) technology uses solar cells to convert solar radiation into electricity at the atomic level. A typical crystalline silicon PV cell of around $12 \mathrm{~cm}$ in diameter and $0.25 \mathrm{~mm}$ thick, is able to generate about 2 watts of electrical power or 4 amperes of direct current (DC) at 0.5 volt in full sunlight [12]. Knier also pointed out that these modules are intended to deliver electricity at a certain voltage while the current developed is directly dependent on the amount of sunlight hitting the surface [12]. A photovoltaic module consists of a number of solar cells which when wired together, form an array as shown in fig. 2. The production of electricity depends mainly on the area of the module or the array. A larger surface will result in greater electricity generation.

When light energy strikes the solar cells, the rise in temperature makes the crystal-lattice atoms to oscillate around their respective steady positions and thus electrons are free to move to the conduction band, a process known as intrinsic conductivity [14]. The higher the temperature of a given semiconductor material, the greater will be the number of electrons migrating to the conduction band, thereby increasing the electrical conductivity accordingly. Electrical power developed from solar cells depends on four main factors, namely; wavelength of sunlight, sunlight intensity, surface area

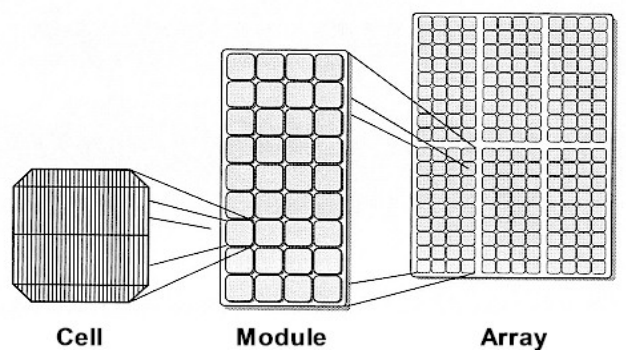

Figure 2. PV solar arrays [13] where the sunlight strikes, and tilt angle. The tilt angle, i.e. the solar panel angle is measured from the horizontal. Maximum power density is generated when the solar panel is adjusted perpendicular to the sun rays. The appropriate tilt angle for Mauritius is $20^{\circ}$ [15] and given its location in the southern hemisphere, the ideal orientation for the panel is to the North [16].

The two categories of PV cells mostly commercialized today are crystalline silicon and thin film. Crystalline silicon cells, also known as first generation PV is a category which includes mono-crystalline and multicrystalline (Poly-crystalline) PV cells. These are the most efficient PV technologies which accounted of approximately $84 \%$ of the total PV-electricity produced in 2008 [17].

Effect of dust

As per ISO 4225:1994(en), dust is described as small solid particles under $75 \mu \mathrm{m}$ in diameter, which settle out under their own weight but which may remain suspended for some time [18]. Most dust particles do not possess a definite geometric diameter and thus particle size is usually expressed as equivalent or effective diameter. The method for determining dust particle size is based on the physical characteristics of the particle volume, its surface area, or mean diameter. According to Hazard Prevention and Control in the Work Environment, HPCWE, the types of dust found in the work environment are mainly in forms of mineral, metallic, chemical, organic and other biohazards types [19].

A better understanding and eventual control of dust deposition on solar panel significantly depend upon the knowledge of the basic dust deposition process mechanics. In the initial adhesion stage, changes in the adhesion process such as condensation and chemical reaction can occur. The aerodynamic behavior of airborne dust particles is a function of multiple parameters. Gravitational Settlement is one of the parameter where diameter, density, and the shape are the dependent factors of particles falling through air. Brownian motion for instance represents particles with random and irregular motions which can be calibrated in terms of mean-square displacements [20].

Other parameters such as Eddy diffusion and electrical charges can also be considered whereby airborne dusts are affected under the influence of turbulent airflow and where particles are charged in induced movement respectively. In coalescence, particles in continuous motion will grow to the point that their terminal velocity becomes so heavy that they fall out of suspension [20]. Solar research carried out over the past few years has revealed a reduction in performance of solar devices due to dust accumulation. The process is seen to vary in various locations over the world. An experiment carried out by Hottel and Woertz in 1942 over a period of 3 month revealed an average of $1 \%$ decrease of incident light striking solar radiation due to dust accumulation on a glass plate tilted at an angle of $30^{\circ}$. The peak reduction observed during the experiment was $4.7 \%$ [21]. 
In 1963 and 1988, Dietz and Michalsky et al. performed an experiment following Hottel and Woertz methodology in the north-eastern United States which also revealed a relatively low reduction in performance [22, 23]. Glass samples between tilt angles of $0^{\circ}$ to $50^{\circ}$ were used by Dietz and showed up to a $5 \%$ diminution in the solar radiation reaching the panel due to dust accumulation [22]. Several noteworthy studies showed large performance variation from place to place as a function of exposure time. Up to $40 \%$ reduction in efficiency of PV panels was determined by Nimmo and Said in 1979, during an experiment carried out over a period of 6 months in Saudi Arabia [24].

El-Shobokshy and Hussein used a controlled laboratory environment in 1993 during which experimental parameters could be maintained, measured and reproduced. Five varieties of laboratory defined dust, namely; limestone (Grade 1,2,3), cement and carbon having distinct and determined physical properties, which are mostly present in the atmosphere, were used. The results showed that the short-circuit current and the power output had similar trends since the dust accumulation did not have any influence on the open-circuit voltage [25].

Based on the performance characteristic, it was concluded that the reduction in the PV performance is not only dependent on the dust accumulation but also on the type of dust and its geometrical property range. Finer dust accumulation on the surface has much greater negative effects on the well-functioning of the PV system than when compared to coarser particles. From the 174 petawatts of incoming solar radiation striking the earth's surface daily, $6 \%$ is reflected while $16 \%$ is absorbed as represented in fig. 3. Dust particles further reduces this absorption which decreases the amount of solar

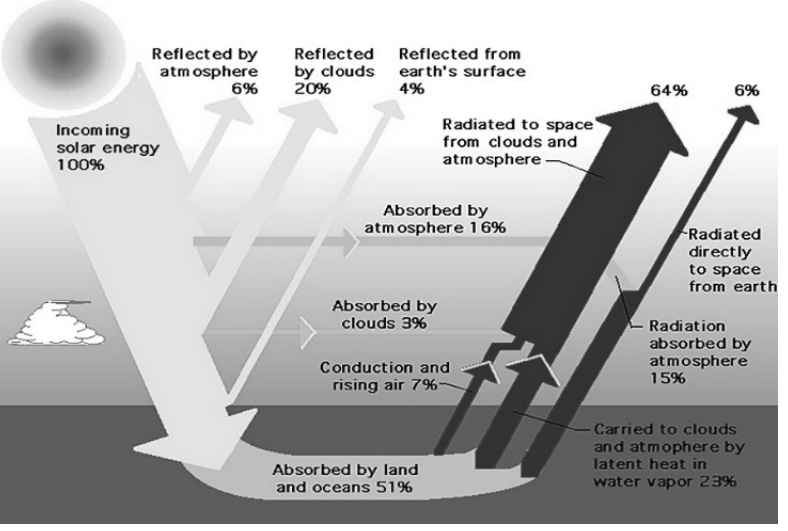
radiation that is received by the earth's atmosphere.

\section{MATERIALS AND METHOD}

In this research study, the main pollutants used were sand, soil and rock sand. Sand was selected since many solar farms might be erected in coastal areas in the near future. Soil particles was selected since they are omnipresent across the island and are relatively light and easily blown away by air. Rock sand or stone crust (basalt particles) was also considered due to their presence in most construction sites. The two recommended particle diameters used in this research, i.e. 63 and 75 microns were obtained after carrying out a filtering process using graduated sieves of $1.18 \mathrm{~mm}, 600 \mu \mathrm{m}, 75 \mu \mathrm{m}$ and $63 \mu \mathrm{m}$. Wet sand, collected from the beach, was allowed to dry for about 4 days under direct sunlight to reduce its moisture content. After the sieving process, two categories of sand particles were produced, namely $75 \mu \mathrm{m}$ and $63 \mu \mathrm{m}$. Soil particles on the other hand, was directly fed into the sieving process as it was already dry in its natural state. In a similar process as for sand preparation, rock sand was left to dry in the sun before undergoing a filtering process to produce particles with an average diameter of $75 \mu \mathrm{m}$ and $63 \mu \mathrm{m}$.

The experimental setup, designed to investigate the effects of air pollutants on PV panels' efficiency, was carried out in Mapou, Mauritius on an artificially polluted panel and was compared to a reference one that was free of pollutants. The solar panels each of $20 \mathrm{~W}$ capacity, were mounted on a wooden stand tilted at an angle of $20^{\circ}$ (fig. 4) [15]. For the case of Mauritius, located in the southern hemisphere, the most suitable PV-panel orientation is to the North [16].

The setup consisted of two monocrystalline solar panels each having a dimension of $255 \mathrm{~mm}$ by $575 \mathrm{~mm}$ with a maximum irradiance

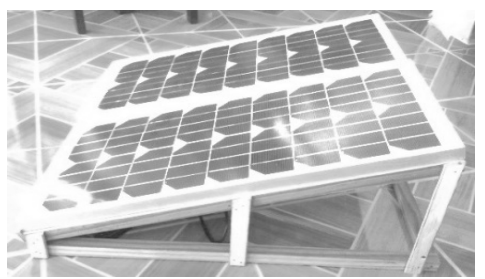

Figure 4. The experimental PV setup of $1000 \mathrm{~W} / \mathrm{m}^{2}$. The maximum power, $P_{\max }$ that could be generated was $20 \mathrm{~W}$. Other components included two millimeters, i.e. an ammeter and a voltmeter, one battery chargestorage, one DC/DC charge controller, a temperature probe, a precision balance, range of filters, a solar power meter and one DC electric load (bulb) of 12V. The 6 single-cell 12 volt battery was connected in series to produce a fully charged output voltage of 12.6 volts [27]. The purpose of the charge controller was to prevent overcharging of batteries while the solar power

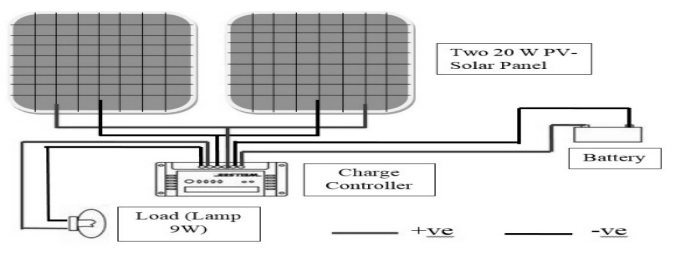

Figure 5. Wiring of PV panel 
meter was used to measure insolation or solar radiation falling on the horizontal surface in $\left[\mathrm{Wm}^{-2}\right]$.

In the particles' deposition process, a sieve was used to uniformly spread 1 gram of one of the three pollutant of 63 microns on a thoroughly cleaned panel. Values for current intensity and voltage output of the PVpanels were then recorded after every 2 -minute interval in a 30-minute period. The ambient temperature readings and the intensity of solar radiation were also recorded using the temperature probe and solar power meter respectively (tab. 1). The panel was thoroughly cleaned with filtered water and cloth before the experiment could be repeated with the remaining pollutants.

\begin{tabular}{|c|c|c|c|c|c|c|}
\hline \multicolumn{3}{|l|}{ Pollutant: } & \multirow{3}{*}{\multicolumn{2}{|c|}{ Clean Panel }} & \multirow{2}{*}{\multicolumn{2}{|c|}{ Polluted Panel }} \\
\hline \multicolumn{3}{|l|}{ Diameter: } & & & & \\
\hline \multicolumn{5}{|l|}{ Mass: } & & \\
\hline $\begin{array}{l}\text { No. of } \\
\text { Experiment }\end{array}$ & $\begin{array}{l}\text { Solar Radiation, } \\
{\left[\mathrm{Wm}^{-2}\right]}\end{array}$ & $\begin{array}{l}\text { Ambient } \\
\text { Temperature, } \\
{\left[{ }^{\circ} \mathrm{C}\right]}\end{array}$ & $\begin{array}{l}\text { Current } \\
\text { intensity, [A] }\end{array}$ & $\begin{array}{l}\text { Voltage } \\
\text { output, [V] }\end{array}$ & $\begin{array}{l}\text { Current } \\
\text { intensity, [A] }\end{array}$ & $\begin{array}{l}\text { Voltage } \\
\text { output, } \\
\text { [V] }\end{array}$ \\
\hline \multicolumn{7}{|l|}{1} \\
\hline 2 & & & & & & \\
\hline
\end{tabular}

Table 1. Parameters to be recorded

Before proceeding with the experimental test, a solar test analysis was carried out to check for any discrepancy between the two panels. A difference of $0.02 \%$ in the efficiency of the two panels showed that they were almost identical.

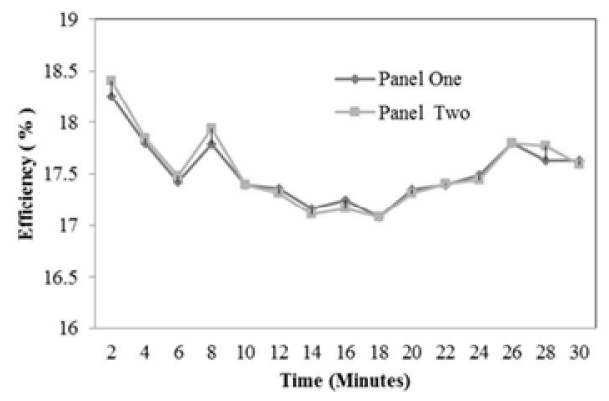

\section{A. Efficiency of solar panels}

Figure 6. Efficiency comparison of both panels

The efficiency of a solar cell is given as the ratio of energy output to input energy from the sun. The input energy depends on the surface area of the cell and the total solar radiation.

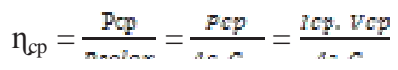

where $\eta_{c p}$ - energy conversion efficiency of clean solar panel, $\mathrm{P}_{\mathrm{cp}}$ - generated power from clean solar panel, $\mathrm{P}_{\text {solar }}$ incident solar power generated, $\mathrm{A}_{\mathrm{c}}$ - surface area of PV panel, $\mathrm{G}_{\mathrm{T}}$ - intensity of solar radiation, $\mathrm{I}_{\mathrm{cp}}$ - current generated by clean solar panel and $V_{c p}$ - voltage generated by clean solar panel. The energy yield reduction percentage is calculated using the following expression:

$$
\mathrm{E}_{\mathrm{Y}}=\frac{F \subset p-F p p}{m} \times 100 \%
$$

where $\mathrm{P}_{\mathrm{pp}}$ - power generated by artificially polluted PV panel.

\section{RESULTS AND DISCUSSION}


For every mass, size and type of pollutant investigated, the power output and efficiency of both the clean and artificially polluted panels were recorded as a function of time as shown in fig. 7 and fig. 8. The average power recorded for the clean and polluted panels were $0.992 \mathrm{~W}$ and $0.681 \mathrm{~W}$ respectively, i.e. a difference of $31.35 \%$. For $6.8 \mathrm{~g} / \mathrm{m}^{2}$ mass per surface area which is equivalent to 1 gram, about $31.6 \%$ loss in the efficiency was recorded.

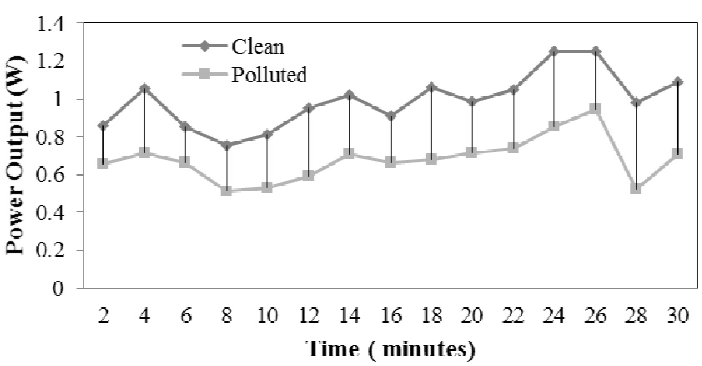

Figure 7. Power output of the clean and polluted panels 1 gram of $63 \mu \mathrm{m}$ soil particles

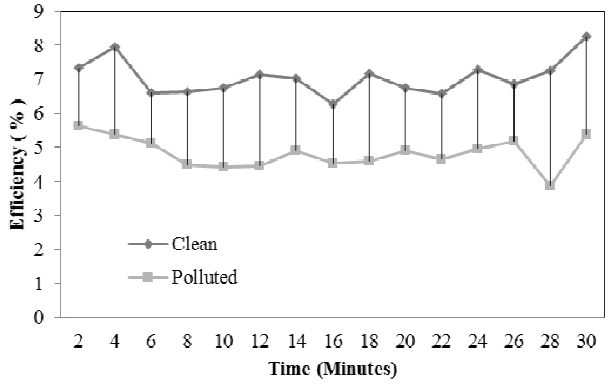

Figure 8. Efficiency of the clean and polluted panels with 1 gram of $63 \mu \mathrm{m}$ soil particles

s of soil pollutant particles of $63 \mu \mathrm{m}$ are summarized in the following bar charts as shown in fig. 9 and fig. 10 below.

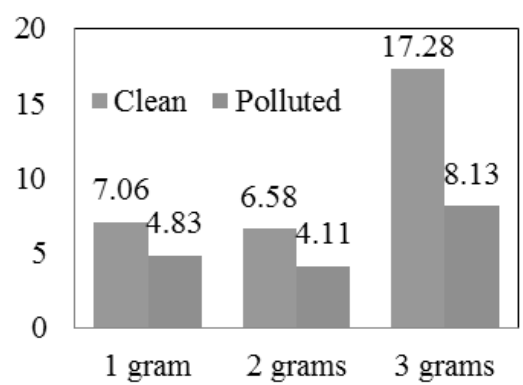

Figure 9. Mean efficiency of clean and polluted panels with 1, 2 and 3 grams of $63 \mu \mathrm{m}$ soil particles

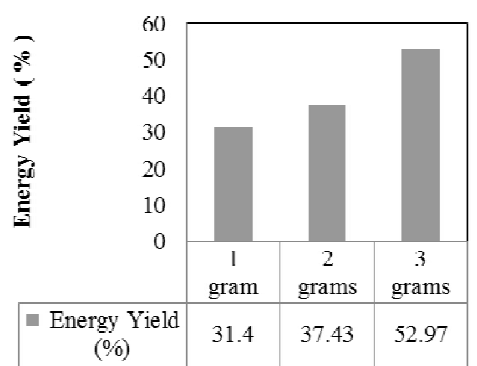

Figure 10. Average energy yield reduction $\%$ for 1,2 and 3 grams of $63 \mu \mathrm{m}$ soil particles

The results obtained with $75 \mu \mathrm{m}$ of soil particles are summarized as follows (fig. 11, fig. 12):

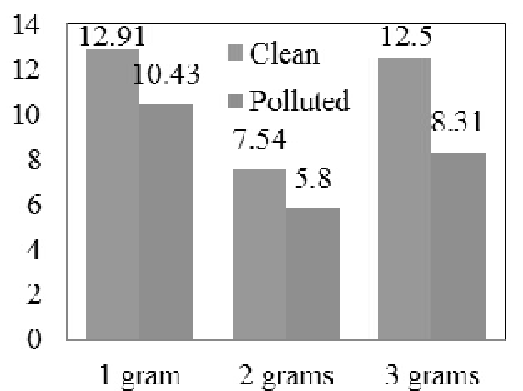

Figure 11. Mean efficiency of clean and polluted panels with 1, 2 and 3 grams of $75 \mu \mathrm{m}$ soil particles

or sand particles' size of 63 and $75 \mu \mathrm{m}$, the recorded data for

efficiency and calculated energy yield reduction percentage in the different categories of masses, are summarized in

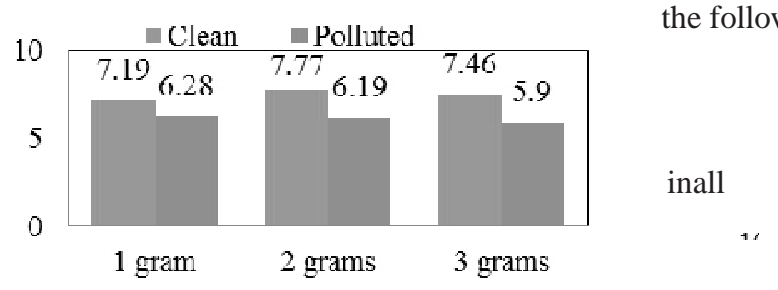

Figure 17. Mean efficiency of clean and polluted panels with 1, 2

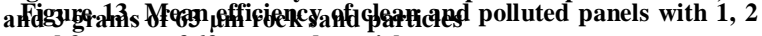
and 3 grams of $63 \mu \mathrm{m}$ sand particles

Figure 15. Mean efficiency of clean and polluted panels with 1, 2 and 3 grams of $75 \mu \mathrm{m}$ sand particles

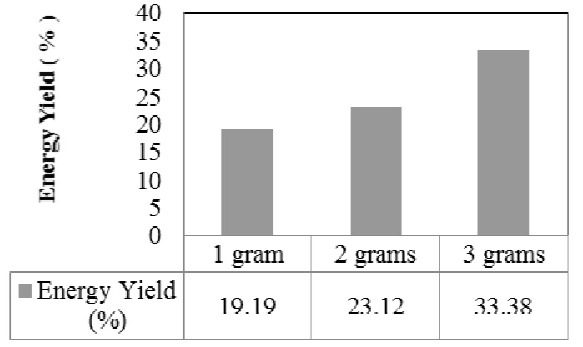

Figure 12. Average energy yield reduction $\%$ for 1,2 and 3 grams of $75 \mu \mathrm{m}$ soil particles following bar charts as shown below in fig. 13 to fig. 16:

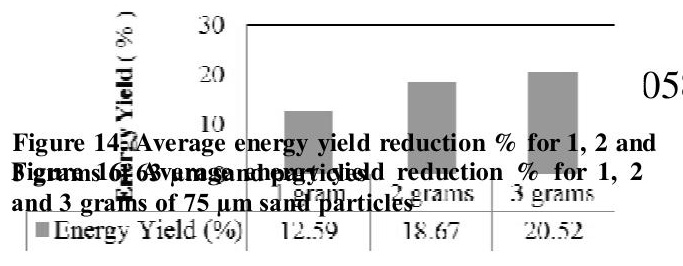


y for rock sand particles' size of 63 and $75 \mu \mathrm{m}$, the efficiency and calculated energy yield reduction percentage data recorded are displayed in the following bar charts (fig. 17 - fig. 20):

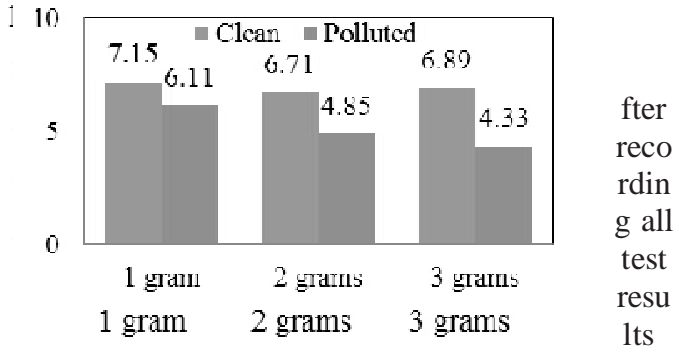

Figure 19. Mean efficiency of clean and polluted panels with 1, 2 and 3 grams of $75 \mu \mathrm{m}$ rock sand particles

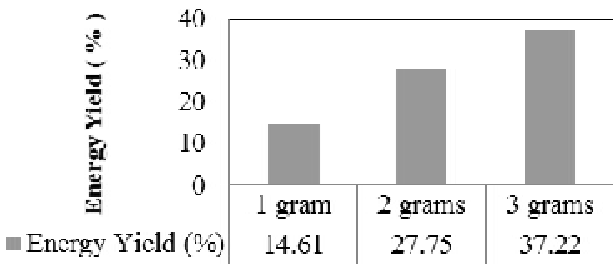

Figure 18. Average energy yield reduction $\%$ for 1,2 and 3 grams of $63 \mathrm{um}$ rock sand narticles

Figure 20. Average energy yield reduction $\%$ for 1, 2 and 3 grams of $75 \mu \mathrm{m}$ rock sand particles

obtained for both 63 and 75 microns of sand, soil and rock sand particles, it was seen that soil particles of had the most significant impact on the generation. The natural molecular of soil has an average percentage composition of $25 \%$ water. Due to this humidity content in soil, i.e. cementation, particles tend to stick easily on surfaces of From the research carried out by Cuddihy soil particles on PV surface tend to form microscopic droplets of salt solutions that

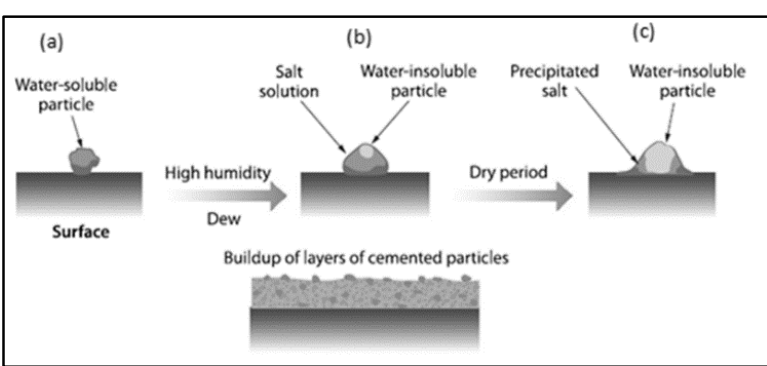

63 microns power structure high the PV panels. in 1983, also retain insoluble particles in high humidity condition [28]. Upon decrease in the humidity content, the precipitated salt acts as a cement and hold the insoluble Figure 21. Dust-moisture cementation process [29] to the surface.

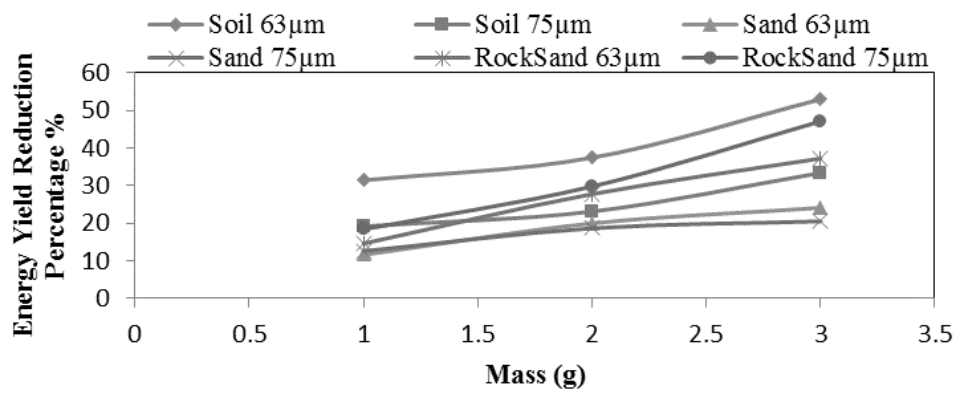

Rock sand particles which were observed to be the second most influential pollutant, behaved up to a similar extent like soil particles as they could undergo into a cementation process. For rock sand of $75 \mu \mathrm{m}$, the highest yield recorded was $46.38 \%$ which reflected the highest blockage of sunlight.

On the other hand, both the 63 and 75 microns of sand particles proved to have the least impact on the efficiency of solar panels mainly due to their non-sticky characteristics. The particles Figure 22. Energy yield reduction percentage for different types of pollutant were observed to roll down and accumulate at the bottom of the panel.

Based on the differences calculated between the masses in each category of pollutant particles as shown in tab. 2, a general increasing trend in the energy yield reduction percentage was observed. The difference is most significant between the 3 grams and 2 grams of pollutant particles, namely in $63 \mu \mathrm{m}$ soil and $75 \mu \mathrm{m}$ rock sand particles at $15.54 \%$ and $17.31 \%$ respectively.

Table 2. Energy yield reduction percentage increment

\begin{tabular}{|c|c|c|c|c|c|c|}
\hline \multirow{2}{*}{ Pollutant } & \multirow{2}{*}{$\begin{array}{l}\text { Size/ } \\
\mu \mathrm{m}\end{array}$} & \multicolumn{3}{|c|}{ Energy Yield Reduction Percentage } & \multirow{2}{*}{$\begin{array}{l}\text { Difference between } 2 \\
\text { grams and } 1 \text { gram/\% }\end{array}$} & \multirow{2}{*}{$\begin{array}{l}\text { Difference between } 3 \\
\text { grams and } 2 \text { grams/\% }\end{array}$} \\
\hline & & 1 gram & 2 grams & 3 grams & & \\
\hline \multirow{2}{*}{ Soil } & 63 & 31.40 & 37.43 & 52.97 & +6.03 & +15.54 \\
\hline & 75 & 19.19 & 23.12 & 33.38 & +3.93 & +10.26 \\
\hline
\end{tabular}




\begin{tabular}{|l|l|l|l|l|c|c||}
\hline \multirow{2}{*}{$\begin{array}{l}\text { Rock } \\
\text { Sand }\end{array}$} & 63 & 14.61 & 27.75 & 37.22 & +13.14 & +9.47 \\
\cline { 2 - 6 } & 75 & 18.37 & 29.78 & 47.09 & +11.41 & +17.31 \\
\hline \multirow{2}{*}{ Sand } & 63 & 11.60 & 19.97 & 24.10 & +8.37 & +4.13 \\
\cline { 2 - 6 } & 75 & 12.59 & 18.67 & 20.52 & +6.08 & +1.85 \\
\hline
\end{tabular}

The test results obtained in this research study were compared to a similar experiment carried out by Kaldelis and Kapsali in 2011 [6]. The main pollutant used there were red soil (diameter $\leq 10 \mu \mathrm{m}$ ), limestone (diameter $\leq 60 \mu \mathrm{m})$ and ash (diameter $\leq 150 \mu \mathrm{m})$.

The results of soil and limestone particles in the two studies were further analyzed. For limestone of 1.51 $\mathrm{g} / \mathrm{m}^{2}$ in the laboratory experiment, an energy yield reduction of approxiamtely10 \% was observed. By using proportionality, as shown in tab. 3, the energy yield reduction for 63 and $75 \mu \mathrm{m}$ of soil particles were calculated as $3.9 \%$ and $2.45 \%$ respectively.

Table 3. Energy yield reduction percentage approximation for $1.51 \mathrm{~g} / \mathrm{m}^{2}$

\begin{tabular}{|l|c|l|l|l||}
\hline \hline Pollutant & \multirow{2}{*}{$\begin{array}{l}\text { Size } \\
/ \mu \mathrm{m}\end{array}$} & $\begin{array}{l}\text { Surface } \\
\text { Density } / \mathrm{g} / \mathrm{m}^{2}\end{array}$ & $\begin{array}{l}\text { Energy Yield Reduction } \\
\text { Percentage }\end{array}$ & $\begin{array}{l}\text { Energy Yield Reduction Percentage } \\
\text { for surface density of } 1.51 \mathrm{~g} / \mathrm{m}^{2}\end{array}$ \\
\cline { 3 - 5 } & 63 & 20.5 & 3 grams & 3.90 \\
\cline { 2 - 5 } & 75 & 20.5 & 52.97 & 2.45 \\
\hline
\end{tabular}

The results however conclusively concurred to the trend established in the research carried out by Kaldelis and Kapsali in 2011 [6]. The increase in the energy yield reduction was found to be inversely proportional to the diameter of the particles. Moreover, it was seen that the energy yield reduction tended to increase exponentially with decreasing particles'diameters.

\section{CONCLUSION}

This study was carried out to investigate the effects of air pollutants namely, sand, soil and rock sand on the efficiency and power output of PV panels. The average diameter of the three particles used were 63 and $75 \mu \mathrm{m}$ and the experimental test was repeated for different masses, namely, 1, 2 and 3 grams. The electrical parameters of two identical PV panels, i.e. a clean and an artificially polluted one were recorded. The test results revealed a net increase in the energy yield reduction percentage with increasing mass content. The pollutant particles to have the most significant impact on the power generation was found to be soil particles of 63 microns followed by rock sand particles of 75 and $63 \mu \mathrm{m}$. In the category of 3 grams of pollutant, the energy yield reduction percentage with $63 \mu \mathrm{m}$ of soil and rock sand particles were found to be $52.97 \%$ and $37.22 \%$ respectively. It was concluded that, due to the cementation process and the naturally high humidity content in soil, the particles tend to adhere more easily on panels' surfaces. On the other hand sand particles of both 63 and $75 \mu \mathrm{m}$ were found to have the least impact on the energy yield reduction percentage. After comparison with results obtained by Kaldelis and Kapsali in 2011, it was deduced that pollution by finer particles will further increase the energy yield reduction percentage [6]. Future research investigation in that field could further elaborate this observation in much more detail and come up with appropriate recommendation to minimize the associated effects.

\footnotetext{
$\mathrm{A}_{\mathrm{c}}$ - surface area of PV panel, $\left[\mathrm{m}^{2}\right]$

$E_{Y}$ - energy yield reduction percentage

$\mathrm{G}_{\mathrm{T}}$ - intensity of solar radiation, $\left[\mathrm{Wm}^{-2}\right]$

$\mathrm{I}_{\mathrm{cp}}$ - current generated by clean solar panel, [A]

MWp - Mega Watt Peak

$\mathrm{P}_{\mathrm{cp}}$ - generated power from clean solar panel, [W]

$\mathrm{P}_{\max }$ - Maximum Power, [W]

$\mathrm{P}_{\mathrm{pp}}$ - power generated by artificially polluted $\mathrm{PV}$ panel, [W]

$\mathrm{P}_{\text {solar }}$ - incident solar power generated, [W]

$\mathrm{V}_{\mathrm{cp}}$ - voltage generated by clean solar panel, [V]

Greek symbols
}

\section{NOMENCLATURE}


$\eta_{\mathrm{cp}}$ - energy conversion efficiency of clean solar panel

\section{REFERENCE}

[1] ***, IS/IEC 61724: 1998: Indian Standard Photovoltaic System Performance Monitoring - Guidelines for Measurement, Data Exchange and Analysis, Bureau of Indian Standards, New Delhi, India, 2010

[2] Frankl, P., et al., Technology Roadmap Solar photovoltaic energy, International Energy Agency (IEA), Paris, France (2010)

[3] ***, Energy Strategy 2011 - 2025, http://publicutilities.gov.mu/English/DOCUMENTS/-ENERGY- STRATEGY.PDF

[4] ***, Green Jobs Assessment Mauritius, http://www.ilo.org/wcmsp5/groups/public/---ed_emp/--emp_ent/documents/publication/wcms_317238.pdf

[5] ***, Maurice Ile Durable, http://mid.govmu.org/portal/sites/mid/file/full\% 20report\%20-midpolicy.pdf

[6] Kaldelis, J. K., Kapsali, M., Simulating the dust effect on the energy performance of photovoltaic generators based on experimental measurements, Energy., 36 (2011), 8, pp. 5154-5161

[7] Jiang, H., et al., Experimental investigation of the impact of airborne dust deposition on the performance of solar photovoltaic (PV) modules, Atmospheric Environment., 45 (2011), 25, pp. 4299-4304

[8] Fenger, J., Air pollution in the last 50 years - From local to global, Atmospheric Environment., 43 (2009), 1, pp. 13-22

[9] Ramanathan, V., Feng, Y., Air pollution, greenhouse gases and climate change: Global and regional perspectives, Atmospheric Environment, 43 (2009), 1, pp. 37-50

[10] Denholm, P., et al., Solar energy: the largest energy resource, Generating electricity in a carbon-constrained world., (2010), pp. 271-302

[11] Goossens, D., Offer, Z. Y., Comparisons of day-time and night-time dust accumulation in a desert region, Journal of Arid Environments 31., (1995) p. 253-281

[12] ***, How do photovoltaics work?, http://science.nasa.gov/science-news/science-at-nasa/2002/solarcells

[13] ***, Solar Arrays, Explained, http://blog.gogreensolar.com/2008/09/solar-arrays-explained.html

[14] Haberlin, H., Solar Cells: Their Design Engineering and Operating Principles, in: PHOTOVOLTAICS System Design and Practice, John Wiley \& Sons, Ltd, United Kingdom, 2012, pp. 79-83

[15] ***, Turning Mauritius Green, http://turningmauritiusgreen.blogspot.com/2009/10/tilt-angle.html

[16] ***, Solar Angle Calculators, http://www.solartradingpost.com/solar-angle-calculators.html

[17] Bartlett, J. E., et al., The Effects of the Financial Crisis on Photovoltaics: An Analysis of Changes in Market Forecasts from 2008 to 2009 , NREL/TP-6A2-46713, National Renewable Energy Laboratory, USA, 2009

[18] ***, ISO 4225:1994(en) Air quality- General aspects - Vocabulary, https://www.iso.org/obp/ui/\#iso:std:iso:4225:ed-2:v1:en

[19] ***, Hazard Prevention and Control in the Work Environment: Airborne Dust, http://www.who.int/occupational health/publications/en/oehairbornedust3.pdf

[20] Sarver, T., et al., A comprehensive review of the impact of dust on the use of solar energy: History, investigations, results, literature, and mitigation approaches, Renewable and Sustainable Energy Reviews., 22 (2013), pp. 698-733

[21] Hottel, H. C., Woertz, B. B., The Performance of Flat Plate Solar-Heat Collectors, Transactions of the ASME, 64 (1942), pp. 64-91

[22] Dietz, A. G. H., Diathermanous materials and properties of surfaces, Introduction to the utilization of solar energy., (1963), pp. 59-86

[23] Michalsky, J. J., et al., Design and development of a rotating shadow band radiometer solar radiation/daylight network, Solar Energy., 41 (1988), 6, pp. 577-581

[24] Nimmo, B., Said, S. A. M., Effects of dust on the performance of thermal and photovoltaic flat plate collectors in Saudi Arabia, Alternative Energy Sources., 1 (1979), pp. 145-152

[25] El-Shobokshy, M. S., Hussein, F. M., Effect of dust with different physical properties on the performance of photovoltaic cells, Solar Energy., 51 (1993), 6, pp. 505-511

[26] ***, Solar In-Depth, http://www.solarcellcentral.com/solar_page.html

[27] ***, Battery Basics, http://www.progressivedyn.com/battery_basics.html

[28] Cuddihy, E. F., Surface soiling: theoretical mechanisms and evaluation of low-soiling coatings, Proceedings, Proceedings of the flat-plate solar array project research forum on quantifying degradation, Virginia, USA, 1983, pp. 379-396

[29] Cuddihy, E. F., Theoretical considerations of soil retention, Solar Energy Materials., 3 (1980), pp. 21-33 